\title{
13. ONSET OF MONSOONAL RELATED UPWELLING IN THE WESTERN ARABIAN SEA AS REVEALED BY PLANKTONIC FORAMINIFERS ${ }^{1}$
}

\author{
Dick Kroon, ${ }^{2}$ Tineke Steens, ${ }^{3}$ and Simon R. Troelstra ${ }^{3}$
}

\begin{abstract}
Quantitative analysis of the late Cenozoic planktonic foraminiferal record from western Arabian Sea Site 722 revealed long term trends in the history of oceanography and climate. The modern western Arabian Sea surface waters are highly influenced by the monsoonal wind system. Summer upwelling, a result of southwestern winds, occurs along the coast of Somalia which produces distinct foraminiferal assemblages which are dominated by $G$. bulloides d'Orbigny. Consequently, variations in the distribution record of $G$. bulloides through time monitor the upwelling history associated with monsoonal activities. G. bulloides was a minor constituent of the foraminiferal fauna from the bottom of the hole ( $\sim 14.5 \mathrm{Ma})$ until about $8.6 \mathrm{Ma}$ ago. Then a rapid shift occurred toward higher values, up to $53 \%$ at $7.4 \mathrm{Ma}$. We interpret this rapid increase as a major step in the evolution of the monsoonal history. It is either the establishment of the system or at least a strong intensification of the monsoonal winds. At $5.5 \mathrm{Ma}$ a significant drop of the G. bulloides relative abundance occurred which may indicate less upwelling, or alternatively other biota may have been favored in this period. From 5.0 Ma to Recent the G. bulloides record indicates that upwelling has occurred with minor fluctuations.
\end{abstract}

\section{INTRODUCTION}

The main objectives for drilling the western Arabian Sea sediments (Fig. 1) were: (1) to document the onset of high productivity as a result of upwelling related to the establishment of the monsoonal wind system and (2) to obtain a Neogene record of monsoonal environmental variability reflected in the associated sediments (Shipboard Scientific Party, 1989a).

The Indian Ocean monsoonal winds produce important oceanic features in the western Arabian Sea, especially during the summer. During this period strong southwesterly winds originate in the Southern Hemisphere and are driven by the gradient between the low pressure cell above the Tibetan Plateau and the Himalayas and the high pressure of the southern Indian Ocean. These winds force upwelling of colder deeper waters along the coasts of Oman and Somalia (for an overview, see Shipboard Scientific Party, 1989a, and references cited therein).

The upwelled waters are colder and richer in nutrients as compared with "normal" tropical surface waters. The increased nutrient levels sustain distinct floral and faunal groups. An important faunal component in this high productivity area is the planktonic foraminiferal group. Arabian Sea extant planktonic foraminifers show a strong response to the upwelling waters in their absolute numbers and species composition (Bé and Hutson, 1977; Kroon, 1988; Kleyne et al., 1988; Auras et al., 1989). The modern assemblage associated with upwelling is dominated by Globigerina bulloides d'Orbigny and Neogloboquadrina dutertrei (d'Orbigny) (Auras et al., 1989). Prell and Curry (1981) studied the horizontal distribution of planktonic foraminifers in "modern" Arabian Sea core top samples and showed that the relative abundance of $G$. bulloides is highly negatively correlated with summer sea surface temperatures. G. bulloides appeared to be a key species in recording the late Pleistocene upwelling history along the coast of Oman (Prell, 1984).

\footnotetext{
${ }^{1}$ Prell, W. L., Niitsuma, N., et al,, 1991. Proc. ODP, Sci. Results, 117: College Station, TX (Ocean Drilling Program).

2 University of Edinburgh, Grant Institute, West Mains Road, Edinburgh EH9 3JW, Scotland, United Kingdom.

3 Institute of Earth Sciences, Free University, P.O. Box 7161, N1-1007 MC Amsterdam, The Netherlands.
}

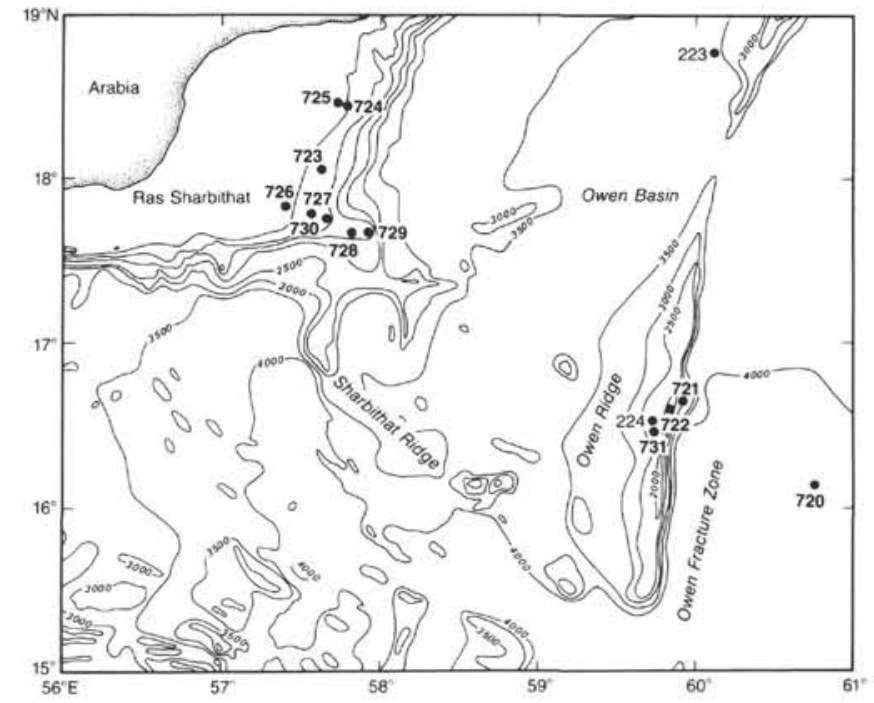

Figure 1. General bathymetry of the northwestern Indian Ocean and ODP Leg 117 study area with locations of ODP and DSDP drill sites. Note that Site 722 is located on the Owen Ridge.

To assess the date of onset of the monsoonal related upwelling and possible late Neogene long term variations in the system, we have counted the relative abundances of the foraminifers in Site 722, which is situated on the Owen Ridge (Fig. 1). Our hypothesis is that variations in relative abundance of $G$. bulloides will be a reflection of changes in the physical, chemical, and biological oceanography of the area.

\section{METHODS}

The upper part of Hole 722A (0-272.55 mbsf) and lower part of Hole 722B (272.55-391.80 mbsf) were sampled every second and fourth section at $65-67 \mathrm{~cm}$ into the core. Additionally, core catcher samples were taken. To extract the foraminifers the samples were washed over a $60 \mu \mathrm{m}$ sieve, and the residues were dried at $50^{\circ} \mathrm{C}$. The foraminiferal residues were sieved over a $125 \mu \mathrm{m}$ sieve, and large samples were split into suitable ali- 
quots of at least 200 specimens. Table 1 is a list of the foraminiferal species which were present. Table 2 shows the relative abundances of those species which are marked with an asterisk in Table 1 .

We converted the depth scale into time by using the ages from the magnetic polarity stratigraphy for the upper part of the hole and biostratigraphy for the lower part as defined by the Shipboard Scientific Party (1989b). The ages for paleomagnetic reversals and biostratigraphic datum levels were in general taken from Berggren et al. (1985).

The absolute age assignment of the first occurrence Neogloboquadrina acostaensis (Blow) is contentious. Berggren et al. (1985) list this event at $10.4 \mathrm{Ma}$ which does not correspond to the western Arabian Sea radiolarian and calcareous nannofossil datum levels. Barron et al. (1985) reported the first occurrence of this species at $8.6 \mathrm{Ma}$ in the equatorial Pacific which is consistent with the datum planes of the other microfossil groups in the western Arabian Sea. Table 3 lists the ages which were used to calculate absolute age assignments of the individual samples by interpolation.

We do not know to what extent dissolution has affected the foraminiferal shells and the relative abundances of species, but we believe that some original signal of surface layer conditions is present.

\section{RESULTS}

To reveal the initiation of upwelling and possible long term trends in the upwelling variations, the relative distribution patterns of individual planktonic foraminiferal species are plotted in Figure 2.

From $14 \mathrm{Ma}$ to $10.8 \mathrm{Ma}$ (middle Miocene to early late Miocene) the foraminiferal fauna was highly dominated by Globorotalia mayeri Cushman and Ellisor (Fig. 2E) and from 10.8 to 8.5 Ma Globigerinita glutinata (Egger) was predominant, associated mainly with $G$. trilobus.

The oldest signal of high productivity, revealed by $G$. bulloides, occurred approximately $8.5 \mathrm{Ma}$ ago in the early late Miocene (Fig. 2A). A sharp increase of its relative abundance marks the onset, or at least a strong intensification of monsoonal activities through upwelling, during this time. Contemporaneously, the relative abundance of $G$. trilobus (Reuss), a species which dominates non-fertile, non-upwelling surface waters (Bé and Hutson, 1977), started to decrease (Fig. 2K). Also, the first appearance of $N$. acostaensis occurred at this time (Fig. 2F). This species is the first representative of the neogloboquadrinid lineage whose end member, Neogloboquadrina dutertrei, is a sig-

Table 1. List of paleomagnetic reversals and faunal events used to calculate numeric ages for the individual samples which were examined for their planktonic foraminiferal content.

\begin{tabular}{lcc}
\hline \multicolumn{1}{c}{ Event } & $\begin{array}{c}\text { Depth } \\
\text { (mbsf) }\end{array}$ & $\begin{array}{c}\text { Age } \\
\text { (Ma) }\end{array}$ \\
\hline B Jaramillo & 38.03 & 0.98 \\
Matuyama/Gauss & 83.20 & 2.47 \\
Gauss/Gilbert & 106.9 & 3.40 \\
T Sidufjall & 142.44 & 4.40 \\
B Thvera & 151.42 & 4.77 \\
Gilbert/Chronozone 5 & 181.49 & 5.35 \\
Chronozone 5/6 & 216.19 & 5.89 \\
B Discoaster quinqueramus & 270.93 & 8.2 \\
B Neogloboquadrina acostaensis & 292.73 & 8.6 \\
T Discoaster hamatus & 305.28 & 8.85 \\
T Globorotalia mayeri & 331.53 & 10.4 \\
T Discoaster kugleri & 378.65 & 13.1 \\
T Globorotalia peripheronda & 392.83 & 14.6 \\
\hline
\end{tabular}

Table 2. References of the recorded planktonic foraminifers. The relative abundances of those species marked with an asterisk are plotted in Table 3.

Beella digitata (Brady) = Globigerina digitata Brady, 1879. Quart. J. Micros. Sci. London, v. 19, p. 286; 1884. London Zoology, pl. 22, v. 9, p. 599, pl. 80, figs. 6-10 (not pl. 82, figs. 6, 7).

*Globigerina bulloides d'Orbigny, 1825. Ann. Sci. Natl., Paris, ser. 1, v. 7, p. 277; Banner and blow, 1960. Cushman Found. Foram. Res. Contrib., v. 11, p. 3 , pl. 1, figs, 1, 4 (lectotype).

Globigerina decoraperta Takayanagi and Saito = Globigerina druryi Akers decoraperta Takayanagi and Saito, 1962. Tohoku Univ. Sci. Rept. 2nd Ser. (Geol.), Spec. v. 5 , p. 85 , pl. 28 , fig. 10 .

* Globigerina druryi Akers, 1955. J. Paleontol. v. 29, n. 4, p. 654, pl. 65, fig. 1

Globigerina nepenthes Todd, 1957, Paleontology, U.S. Geol. Surv., Prof. Paper $280-\mathrm{GH}$, p. 301 , pl. 78 , fig. 7.

*Globigerina rubescens Hofker, 1956. Copenhagen Univ. Zool. Museum, v. 15, p. 234 , pl. 35 , figs. $18-21$.

* Globigerinella aequilateralis (Brady) = Globigerina aequilateralis Brady, 1879. Quart. J. Micros. Sci., v. 19, p. 285.

Globigerinella calida (Parker) = Globigerina calida Parker, 1962 Micropaleontology, v. 8 , p. 221 , pl. 1 , figs. 9-13, 15 .

* Globigerinita glutinata (Egger) = Globigerina glutinata Egger, 1893. Abhandl K. Bayer. Akad. Wiss. Munchen, Math.-Physik., clII, v. 18, p. 371, pl. 13, figs. 19-21.

*Globigerinoides conglobatus (Brady) = Globigerina conglobata Brady, 1879 Quart. J. Micros. Sci., v. 19, p. 286, pl. 80, figs 1-3.

Globigerinoides fistulosus (Schubert) = Globigerina fistulosa Schubert, 1910 Geol. Reichsanst. Verhandl. Wien, p. 323, fig. 2.

- Globigerinoides ruber (d'Orbigny) = Globigerina rubra d'Orbigny, 1839. In de la Sagra, Foraminiferes: Hist. Phys. Pol. Nat. Cuba, p. 82, pl. 4, figs. 12- 14.

*Globigerinoides obliquus Bolli, 1957. U.S. Natl. Museum, Bull. 215, p. 113, pl. 25 , figs. 9,10 ; p. 112 , fig. 21.

* Globigerinoides trilobus (Reuss) = Globigerina triloba Reuss, 1850. K. Akad. Wiss. Wien, Math.- Nat. Cl., Denkschr., v. 1, p. 474, pl. 47, fig. 11.

* Globigerinoides sacculifer (Brady) = Globigerina sacculifera Brady, 1877. Geol. Mag., London, v.4, n. 12, p. 535, no fig.

Globigerinoides tenellus Parker, 1958. Swedish Deep-Sea Exped. 1947-1948: Rept., fasc. 2, p. 280 , pl. 6, figs. 7-11.

*Globoquadrina altispira (Cushman and Jarvis) = Globigerina altispira Cushman and Jarvis, 1936. Cushman Lab. Foram. Res. Contrib., v. 12, p. 5, pl. 1, figs. $13,14$.

*Globoquadrina dehiscens (Chapman, Parr and Collins) = Globorotalia dehiscens Chapman, Parr and Collins, 1934. Linn. Soc. London (Zool), v. 38, p. 569, pl. 11, fig. 36 .

Globoquadrina venezuelana $(\mathrm{Hedberg})=$ Globigerina venezuelana Hedberg. 1937. J. Paleontol., v. 11, p. 681 , pl. 92 , fig. 7 .

Globorotalia birnageae Blow, 1959. Bull. Am. Paleontol., Ithaca, NY, v. 39, p. 210 , pl. 17, fig. 108 .

* Globorotalia crassaformis (Galloway and Wissler) = Globigerina crassaformis Galloway and Wissler, 1927. J. Paleontol., v. 1, p. 41, pl. 7, fig. 12.

Globorotalia fohsi Cushman and Ellisor, 1939. Contr. Cushman Lab. Foram. Res., v. 15 , p. 12 , pl. 2 , fig. 6 .

Globorotalia limbata (Fornasini) = Rotalia limbata d'Orbigny, 1902. Roy. Accad. Sci. Inst. Bologna, Mem. Sci. Natl. Ser. 5, v. 10, p. 56, fig. 55.

* Globorotalia mayeri Cushman and Ellisor, 1939, Contr. Cushman Lab. Foram. Res., v. 15 , p. 11 , pl. 2 , fig. 4.

Globorotalia margaritae Bolli and Bermudez, 1965. Venezuelan Asoc. Geol. Min. Petr. Bol. Inform., v. 8, p. 139, pl. 1, figs. 16-18.

*Globorotalia menardii (Parker, Jones and Brady) = Rotalia menardii d'Orbigny, 1826. Ann. Sci. Natl., Paris, v. 7., p. $273=$ Rotalia menardii Parker, Jones and Brady, 1865. Ann. Mag. Nat. Hist., London, ser. 3, v. 16, p. 20, pl. 3, fig. 81.

Globorotalia peripheroacuta Blow and Banner, 1959. Paleontology, v. 12, p. 22 , pl. 1 , fig. 2.

Globorotalia peripheroronda Blow and Banner, 1966. Micropaleontology, v. 12, p. 294, pl. 1, fig. 1.

- Globorotalia plesiotumida Blow and Banner = Globorotalia (Globorotalia) tumida plesiotumida Blow and Banner, 1965. In Banner and Blow, Nature, v. 207 , p. 1353 , figs. $2 a-c$.

* Globorotalia scitula (Brady) = Pulvinulina scitula Brady, 1882. Roy. Soc. Edinburgh Proc., v. 11 (1880-1882), p. 716; Banner and Blow, 1960. Cushman Found. Foram. Res. Contrib., v. 11, p. 27, pl. 5, fig. 5 (lectotype).

Globorotalia theyeri Fleisher, 1974. Init. Repts. of the Deep Sea Drill. Proj., v. 23, p. 1028 , pl. 12 , fig. 9 ; pl. 13, figs. 1-5.

Globorotalia tosaensis Takayanagi and Saito, 1962. Tohoku Univ., Sci. Rept. Geol., v. 5, p. 81 , pl. 28 , figs. 11,12 .

Globorotalia truncatulinoides (d'Orbigny) = Rotalina truncatulinoides d'Orbigny, 1839. In Barker-Webb et Berthelot, Hist. Natl. Iles Canaries, "Foraminiferes", v. 2, p. 132, pl. 2, figs. 25-27.

* Globorotalia tumida (Brady) = Pulvinulina menardii (d'Orbigny) var. tumida Brady, 1877. Geol. Mag., London, n.s., decade 2, v. 4, p. 535 = Pulvinulina Brady, 1884. Rept. Voy. Challenger Zool, London v. 9, pl. 103, figs. 4-6. 
Table 2 (continued).

Globorotalia ungulata Bermudez, 1960. Dir. Geol., Bol. Geol., Publ. Espec. 3 (Congr., Geol. Venezolana, III, 1960, Mem.), v. 3, p. 1304, pl. 15, fig. 6.

- Globorotaloides hexagona (Natland) = Globigerina hexagona Natland, 1938. Univ. Calif. Scripps Inst. Oceanogr. Bull., Tech. Ser., v. 4 n. 5 p. 149 pl. 7 fig. 1.

- Neogloboquadrina acostaensis (Blow) = Globorotalia acostaensis Blow, 1959. Am. Paleont., Bull., v. 39, p. 208, pl. 17, fig. 106.

*Neogloboquadrina dutertrei (d'Orbigny) = Globigerina dutertrei d'Orbigny, 1839. In de la Sagra, Foraminiferes: Hist. Phys. Pol. Nat. Cuba, p. 84, pl. 4, figs. 19-21; Banner and Blow, 1960. Cushman Found. Foram. Res. Contrib., v. 11 , p. 12 , fig. 1 (lectotype).

Neogloboquadrina humerosa (Takayanagi and Saito) $=$ Globorotalia humerosa Takayanagi and Saito, 1962. Tohoku Univ. Sci. Rept. 2nd. Ser. (Geol.), Spec. v. 6 , p. 78 , pl. 28 , figs. 1,2 .

* Neogloboquadrina nigriniae (Fleisher) = Turborotalia (Turborotalia) nigriniae Fleisher, 1974. Init. Repts. of the Deep Sea Drill. Proj., v. 23, p. 1036, pl. 20, figs. 1-5.

- Neogloboquadrina pachyderma (Ehrenberg) = Aristerospina pachyderma Ehrenberg, 1861. K. Preuss. Akad. Wiss. Berlin, Monatsber., p. 303; 1873. K. Akad. Wiss. Berlin, Abhandl., Jahrg. 1872., p. 386, pl. 1, fig. 4.

Neogloboquadrina pseudopima (Blow) = Globorotalia (Turborotalia) acostaensis pseudopima Blow, 1969. Internat. Conf. Plankt. Microfoss. Proc., v. 1, p. 387 , pl. 35 , figs. $1-7$.

Neogloboqudrina tegillata Bronnimann \& Resig = Globorotalia (Turborotalia) acostaensis Blow tegillata Brönnimann \& Resig, 1971, Init. Repts. of the Deep Sea Drill. Proj., v. 7, p. 1277, pl. 33, fig. 3.

Orbulina universa d'Orbigny, 1839. In de la Sagra, Foraminifères: Hist. Phys. Pol. Natl. Cuba, p. 3, pl. 1, fig. 1.

*Sphaeroidinella dehiscens (Parker and Jones) = Sphaeroidina bulloides d'Orbigny var. dehiscens Parker and Jones, 1865. Roy. Soc. London Phil. Trans., v. 155 , p. 369 , pl. 19 , fig. 5 .

- Sphaeroidinellopsis seminulina (Schwager) = Globigerina seminulina Schwager, 1866. Novara Expedition, 1857-1859, Geol.,v. 2, p. 256, pl. 7, fig. 112.

*Pulleniatina obliquiloculata (Parker and Jones) = Pullenia sphaeroides (d'Orbigny) var. obliquiloculata Parker and Jones, 1865. Roy. Soc. London, Philos. Trans. 155, p. 368, pl. 19, fig.4; Banner and Blow, 1960. Cushman Found. Foram. Res. Contr., v. 11, p. 25, 40, pl. 7, fig. 4 (lectotype).

-Pulleniatina primalis Banner and Blow, 1967. Micropaleontology, v. 13, p. 142, pl. 1 , figs. $1-8$; pl. 3, fig. 2.

Pulleniatina spectabilis Parker, 1965. Contr. Cushman Found. Foram. Res., v. 16, p. 151 , figs. 1-4.

nificant component of the planktonic foraminiferal group in the modern Arabian Sea upwelling area (Bé and Hutson, 1977; Kroon, 1988). Around 5.5 Ma the relative abundance of $G$. bulloides (Fig. 2A) suddenly dropped almost to nothing, and $G$. glutinata shows the reverse with a sharp increase to $50 \%$ (Fig. 2B). By $5.0 \mathrm{Ma}$ the assemblage again was dominated by $G$. bulloides. $N$. acostaensis displays a similar decline in abundance at $5.5 \mathrm{Ma}$ but differs in that its frequency was not reestablished. The highest $G$. bulloides abundance is about 4.0 Ma (Fig. 2A) and is associated with Neogloboquadrina nigriniae (Fleisher) (Fig. 2G). From 3.4 to $2.8 \mathrm{Ma}$ it was difficult to separate $G$. bulloides from $G$. glutinata (period marked by a question mark in Figs. 2A and $\mathrm{B}$ ) because the specimens were badly preserved which made identification impossible.

From 2.8 Ma to Recent, the G. bulloides record fluctuates rapidly (Fig. 2A), and Neogloboquadrina pachyderma (Ehrenberg) and Neogloboquadrina dutertrei (d'Orbigny) increased their relative abundances.

\section{DISCUSSION}

The Neogene planktonic foraminiferal biogeography of the Indian Ocean has been studied by Wright and Thunell (1988) by using core material from 15 DSDP sites. Their quantitative analysis of foraminiferal abundances in successive portions of time shows the development of different biogeographic provinces mainly as a response to global climate changes since the middle and late Miocene. Enhanced north-south provincialization occurred during that time which in turn reflects the environmental conditions of the individual foraminiferal species.
G. bulloides and its ancestor G. praebulloides were mainly present in the transitional and subpolar provinces which indicates that these species had a strong preference for colder, nutrient-rich waters, in fact very similar to the present day distribution of $G$. bulloides (Bé and Hutson, 1977). This implies that $G$. bulloides did not change its ecological preference through time. Therefore the presence of $G$. bulloides or merely an increase in its relative abundance in the middle or late Miocene western Arabian Sea sediments points to upwelling of colder, nutrientrich deeper waters like the present day as a response to the establishment of the monsoon or a strengthening of the system, if it already existed.

Wright and Thunell (1988) included Gulf of Aden Site 231 in their study. They reported $G$. bulloides percentages up to $1 \%$ in the early Miocene, $7 \%$ in the middle Miocene, $10 \%$ in the early Pliocene, and only $3 \%$ in the late Pliocene. They concluded from these $G$. bulloides frequencies that the existence of a monsoonal system was not very much evidenced and rather uncertain. The western Arabian Sea $G$. bulloides relative abundance record of Site 722, however, shows a significant increase around 8.5 Ma ago with a noted maximum amplitude of almost $53 \%$ at 7.4 Ma (Fig. 3), which must have been an effect of upwelling waters in the area. The surface waters of the Gulf of Aden apparently have suffered different oceanographic conditions compared to the western Arabian Sea. From the Site 722 foraminiferal record it appears that a major ecological change took place at about $8.5 \mathrm{Ma}$, assuming that our age model is right; we attribute this to a main event in the monsoonal system. Either it represents the initiation of winds blowing in a south-north direction rather than in an west-east direction forcing upwelling during the summer or it represents a significant intensification of already established monsoonal winds.

Quade et al. (1989) studied the isotopic composition of carbonate derived from a north Pakistan paleosol record over the past $18 \mathrm{Ma}$. This record reflects the vegetation cover in an area which is nowadays very much influenced by the monsoon with a strong seasonal rainfall distribution. They found a large shift at 7.4 Ma which was explained by a dramatic change in the vegetation cover from forests to grasslands which they relate to a major climatic change, probably associated with the inception of the monsoon. The fact that this change was dated approximately $1 \mathrm{~m}$.y. younger than the $G$. bulloides record may either reflect a delayed response of the vegetation cover compared to the intensification of upwelling or dating problems.

Rahman and Roth (1990) provided a reconstruction of the northwestern Indian Ocean oceanography on the basis of variations in the relative abundances of certain calcareous nannofossils. Their material was derived from Gulf of Aden sites and they found that a colder interval started at $10.7 \mathrm{Ma}$. This is not consistent with the $G$. bulloides record. Subtle changes of the environment and different responses of the biota may explain this discrepancy.

Whitmarsh et al. (1974) reported a silica increase in the late middle Miocene at Sites 223 and 224 which they attributed to increased fertility. A similar increase in biogenic opal was found in Site 722 at 11.5-12.0 Ma (Shipboard Scientific Party, 1989b), $\sim 2$ Ma prior to the large shift in the $G$. bulloides record. However, the radiolarians and diatoms are of a tropical origin rather than indicative of upwelling (Shipboard Scientific Party, 1989b).

Unfortunately, our sample density was not high enough to draw thorough conclusions about the upwelling variations since 8.5 Ma. To get a better insight in the fluctuations we have plotted in Figure 3 both the $G$. bulloides and the Globigerinoides sp. record. The latter is a summation of all Globigerinoides species. Modern Globigerinoides species have a prevalence for subtropical-tropical surface waters with an oligotrophic character 
Table 3. List of relative abundances of selected planktonic foraminifers. For a reference see Table 2.

\begin{tabular}{|c|c|c|c|c|c|c|c|c|c|c|c|c|c|c|}
\hline $\begin{array}{l}\text { Depth } \\
\text { (mbsf) }\end{array}$ & $\begin{array}{c}\text { Age } \\
(\mathrm{Ma})\end{array}$ & G. crass. & G. quinq. & G. rubes & N. dut. & G. congl. & P. obliq. & G. tum. & N. nig. & G. sacc. & G. marg. & P. prim. & G. aeq & N. pach. \\
\hline 2.15 & 0.04 & 0.4 & 0.7 & 6.7 & 4.9 & 0 & 3.4 & 0.7 & & 0.4 & & & 0.4 & 1.9 \\
\hline 5.15 & 0.13 & 0 & 4.2 & 6.2 & 11.8 & 1.4 & 0 & 0 & & 0.7 & & & 1.4 & 18.1 \\
\hline 11.95 & 0.28 & 2.1 & 2.1 & 2.1 & 6.9 & 0 & 1.4 & 0.7 & & 0.7 & & & 0 & 0.7 \\
\hline 14.95 & 0.36 & 0 & 0.9 & 2.6 & 6.8 & 0 & 5.1 & 0 & & 0 & & & 0 & 0 \\
\hline 21.55 & 0.59 & 0.7 & 1.3 & 3.3 & 8 & 0 & 0 & 0 & & 1.3 & & & 0.7 & 0.7 \\
\hline 24.55 & 0.66 & 0 & 0 & 2.2 & 11 & 0 & 2.9 & 0 & & 0 & & & 0.7 & 0 \\
\hline 31.15 & 0.8 & 1.2 & 2.9 & 5.3 & 10 & 0 & 2.4 & 0 & & 1.2 & & & 0.6 & 0.6 \\
\hline 34.15 & 0.86 & 0 & 3.7 & 3 & 8.2 & 0 & 5.2 & 0 & & 0.7 & & & 1.4 & 0 \\
\hline 40.75 & 1.07 & 0 & 0 & 0 & 2.3 & 0 & 1.2 & 0 & & 0.6 & & & 0 & 0 \\
\hline 43.75 & 1.17 & 0 & 0 & 1.5 & 6.9 & 0 & 1.5 & 0 & & 0 & & & 0.8 & 6.9 \\
\hline 50.35 & 1.39 & 0 & 0 & 0 & 2.1 & 0 & 5.2 & 2.1 & & 2.1 & & 0 & 0 & 1 \\
\hline 53.35 & 1.49 & 0 & 0 & 3.3 & 6.5 & 0 & 6.5 & 5.4 & & 0 & & 1.1 & 0 & 5.4 \\
\hline 59.65 & 1.69 & 0 & 0 & 0 & 7.5 & 0 & 1.3 & 0 & & 0 & & 0 & 0.6 & 0 \\
\hline 62.65 & 1.79 & 1.2 & 0.6 & 1.2 & 6.5 & 0.6 & 4.2 & 0.6 & & 0 & & 0 & 0 & 4.8 \\
\hline 69.35 & 2.01 & 0 & 0 & 0.6 & 1.1 & 0.6 & 1.7 & 2.2 & & 0.6 & & 0 & 0 & 2.8 \\
\hline 78.95 & 2.33 & & & 0 & 1.5 & 0 & 8.5 & 0 & & 0.8 & & 1.5 & 0.8 & 0.8 \\
\hline 91.65 & 2.79 & & & & 1 & 1 & 2 & 3 & & 0 & & 1 & 0 & 2 \\
\hline 98.35 & 3.06 & & & & 0 & 0 & 2.9 & 11.1 & & 0 & & 0 & 0 & 0 \\
\hline 101.35 & 3.18 & & & & & 0 & 0 & 5.6 & 0 & 0 & 0 & 0 & 0 & 1 \\
\hline 108.05 & 3.43 & & & & & 1 & 2.1 & 7.3 & 9.9 & 1 & 1 & 0 & 0 & 1 \\
\hline 111.05 & 3.52 & & & & & 0 & 0 & 9.6 & 5.2 & 1.5 & 0 & 0 & 0 & 0.7 \\
\hline 117.75 & 3.71 & & & & & & 2.5 & 5.7 & 22 & 1.3 & 0.6 & 0 & 1.3 & 0 \\
\hline 120.75 & 3.79 & & & & & & 1.5 & 4.6 & 8.5 & 0.8 & 1.5 & 0 & 0 & 0 \\
\hline 127.45 & 3.98 & & & & & & 0.9 & 5.3 & 10.6 & 0.9 & 0.9 & 0.9 & 0 & 0 \\
\hline 130.45 & 4.06 & & & & & & 0 & 1.1 & 4.3 & 0 & 0 & 0 & 0 & 0 \\
\hline 137.05 & 4.25 & & & & & & 0 & 1.7 & 11.3 & 0 & 0 & 1.7 & 0 & 0 \\
\hline 140.05 & 4.33 & & & & & & 0.7 & 0.7 & 6.9 & 0.7 & 0.7 & 0.7 & 0.7 & 0 \\
\hline 146.75 & 4.58 & & & & & & 0 & 0 & 0 & 0 & 0 & 3.1 & 0 & 0.8 \\
\hline 149.75 & 4.7 & & & & & & & 3.7 & 0 & 0.9 & 0 & 0.9 & 0 & 0.9 \\
\hline 156.45 & 4.87 & & & & & & & 8 & 0 & 0 & 0 & 1.5 & 0 & 0 \\
\hline 168.18 & 5.09 & & & & & & & 0 & 1.3 & 0 & 0 & 0 & 0 & 0 \\
\hline 185.5 & 5.41 & & & & & & & & 0 & 0 & 0 & 0 & 0 & 0 \\
\hline 188.45 & 5.46 & & & & & & & & & 0 & 2.6 & 0 & 0 & 0 \\
\hline 195.15 & 5.56 & & & & & & & & & 1 & 0 & 0 & 0 & 0 \\
\hline 204.85 & 5.71 & & & & & & & & & 0 & 0.8 & 1.6 & 0 & 0 \\
\hline 207.85 & 5.76 & & & & & & & & & & 0 & 0 & 0.7 & 0.7 \\
\hline 214.55 & 5.86 & & & & & & & & & & & & 0 & 0.7 \\
\hline 251 & 7.36 & & & & & & & & & & & & & 0 \\
\hline 253.15 & 7.42 & & & & & & & & & & & & & \\
\hline 270.4 & 8.18 & & & & & & & & & & & & & \\
\hline 272.55 & 8.23 & & & & & & & & & & & & & \\
\hline 276.25 & 8.3 & & & & & & & & & & & & & \\
\hline 285.3 & 8.46 & & & & & & & & & & & & & \\
\hline 288.95 & 8.53 & & & & & & & & & & & & & \\
\hline 290.45 & 8.56 & & & & & & & & & & & & & \\
\hline 306.85 & 8.94 & & & & & & & & & & & & & \\
\hline 316.45 & 9.51 & & & & & & & & & & & & & \\
\hline 333.7 & 10.52 & & & & & & & & & & & & & \\
\hline 338.85 & 10.82 & & & & & & & & & & & & & \\
\hline 348.55 & 11.38 & & & & & & & & & & & & & \\
\hline 382.2 & 13.48 & & & & & & & & & & & & & \\
\hline 391.8 & 14.49 & & & & & & & & & & & & & \\
\hline
\end{tabular}

(Bé and Hutson, 1977). Intervals with high frequencies of Globigerinoides $\mathrm{sp}$. reflect periods during which the surface waters were not nourished by upwelling. For the most part the curves are antithetic which documents the periods with major and less upwelling.

We conclude that the western Arabian Sea planktonic foraminiferal record contains the history of monsoonal upwelling. A major event occurred at $8.5 \mathrm{Ma}$ which probably documents the initiation of the system. Since that time upwelling has been present according to the $G$. bulloides record with the exception of a short period centered at 5.5 Ma. However, the sample density was low and does not allow us to draw too many conclusions, and other groups of biota may have been in competition with the foraminifers during the various upwelling periods.

\section{REFERENCES}

Auras-Schudnagies, A., Kroon, D., Ganssen, G. M., Hemleben, C., and Van Hinte, J. E., 1989. Biogeographic evidence from planktic foraminifers and pteropods for Red Sea anti-monsoonal surface currents. Deep-Sea Res., 10:1515-1533.
Barron, J. F., Nigrini, C. A., Pujos, A., Saito, T., Theyer, F., Thomas, E., and Weinreich, N., 1985. Synthesis of biostratigraphy; central equatorial Pacific, Deep Sea Drilling Project, Leg 85: Refinement of Oligocene to Quaternary biochronology. In Mayer, L., Theyer, F., Thomas, E., et al., Init. Repts. DSDP, 85. Washington (U.S. Govt. Printing Office), 905-934.

Bé, A.W.H., and Hutson, W.H., 1977. Ecology of planktonic foraminifera and biogeographic patterns of life and fossil assemblages in the Indian Ocean. Micropaleontology, 23:369-414.

Berggren, W. A., Kent, D. V., and van Couvering, J. A., 1985. Neogene geochronology and chronostratigraphy. In Snelling, N. J. (Ed.). The Chronology of the Geological Record. J. Geol. Soc. London, 10: 211-260.

Fleisher, R. L., 1974. Cenozoic planktonic Foraminifera and biostratigraphy, Arabian Sea Deep Sea Drilling Project, Leg 23A. In Whitmarsh, R. B., Weser, O. E., Ross, D. A., et al., Init. Repts. DSDP, 23. Washington (U.S. Govt. Printing Office), 1001-1072.

Kleijne, A., Kroon, D., and Zevenboom, W., 1989. Phytoplankton and foraminiferal frequencies in northern Indian Ocean and Red Sea surface waters. Neth. J. Sea Res., 24:531-539.

Kroon, D., 1988. Distribution of extant planktic foraminiferal assemblages in Red Sea and northern Indian Ocean surface waters. In 
Table 3. (continued)

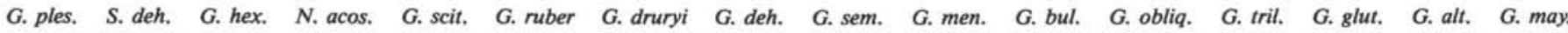

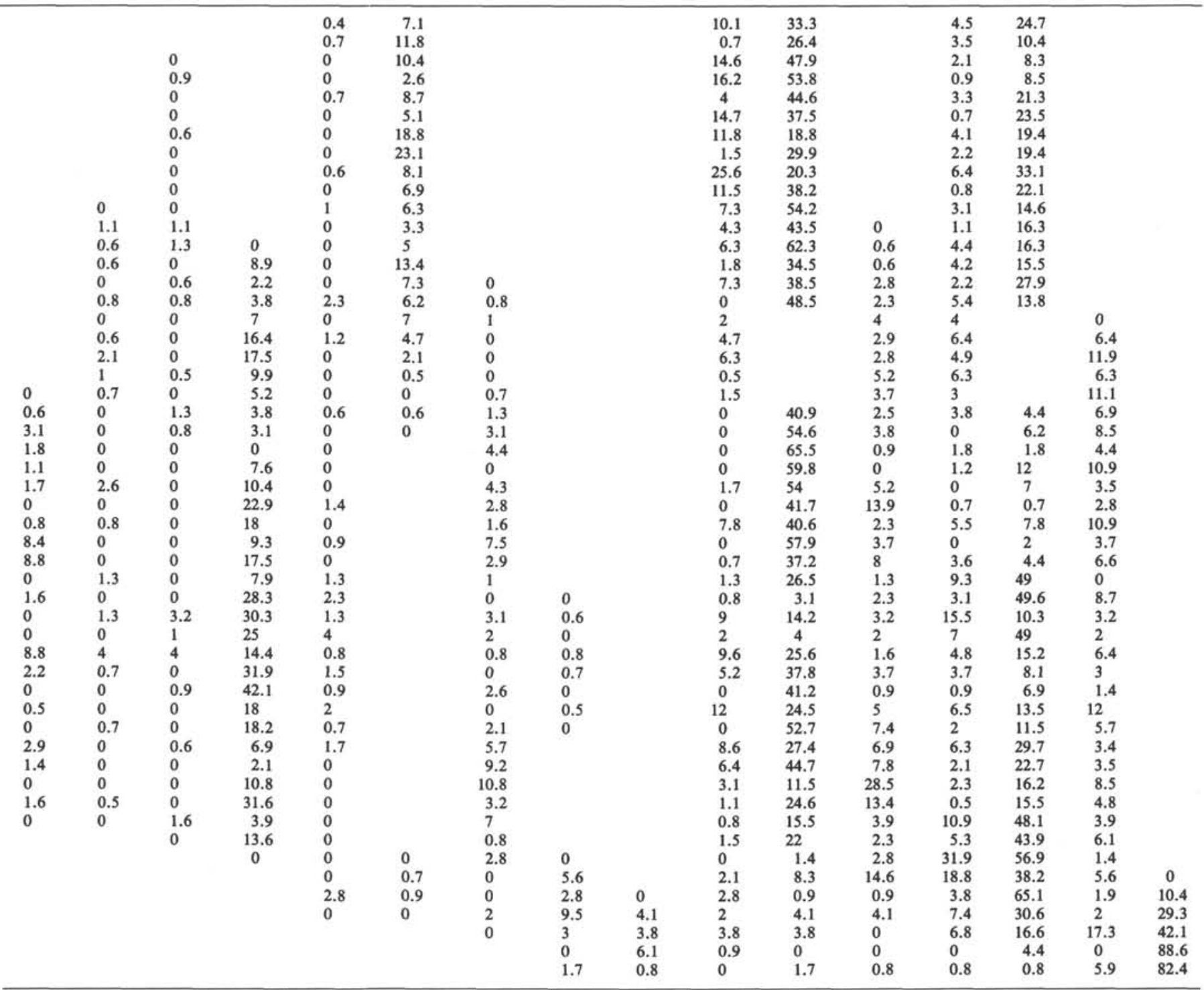

Brummer, G. A., and Kroon, D. (Eds.). Planktonic foraminifers as tracers of ocean-climate history: Amsterdam (Free Univ. Press), 229-267.

Prell, W. L., 1984. Monsoonal climate of the Arabian Sea during the late Quaternary: a response to changing solar radiation. In Berger, A., Imbrie, J., Hays, J., Kukla, G., and Saltzman, B. (Eds.), Milankovitch and climate. Dordrecht (D. Reidel), 349-366.

Prell, W. L., and Curry, W. B., 1981. Faunal and isotopic indices of monsoonal upwelling: western Arabian Sea. Oceanol. Acta, 4:9198.

Quade, J., Cerling, T. E., and Bowman, J.R., 1989. Development of Asian Monsoon revealed by marked ecological shift during the latest Miocene in northern Pakistan. Nature, 342:163-166.

Rahman, A., and Roth, P.H., 1990. Late Neogene paleoceanography and paleoclimatology of the Gulf of Aden region based on calcareous nannofossils. Paleoceanography, 5:91-107.

Shipboard Scientific Party, 1989a. Introduction, background, and major objectives for ODP Leg 117 (western Arabian Sea) in search of ancient monsoons. In Prell, W. L., Niitsuma, N., et al., Proc. ODP, Init. Repts., 117: College Station, TX (Ocean Drilling Program), 510.

1989b. Background and summary of drilling results-Owen Ridge. In Prell, W. L., Niitsuma, N., et al., Proc. ODP, Init. Repts., 117: College Station, TX (Ocean Drilling Program), 35-42.

Whitmarsh, R. B., 1974. Summary of general features of Arabian Sea and Red Sea Cenozoic history based on Leg 23 cores. In Whitmarsh, R. B., Weser, O. E., Ross, D. A., et al., Init. Repts. DSDP, 23: Washington (U.S. Govt. Printing Office), 1115-1124.

Wright, J. D., and Thunell, R. C., 1988. Neogene planktonic foraminiferal biogeography and paleoceanography of the Indian Ocean. Micropaleontology, 34:193-216.

Date of initial receipt: 20 October 1989

Date of acceptance: 27 August 1990

Ms 117B-126 
A

क G. bulloides

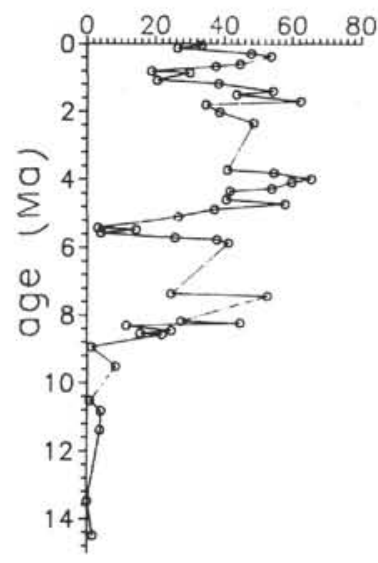

F $\quad$ G

\% N. acostaensis

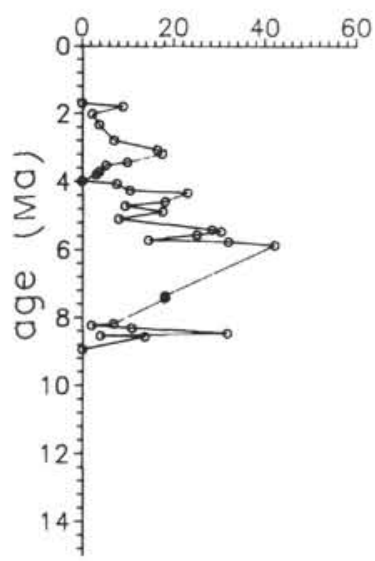

B C

\% G. glutinato

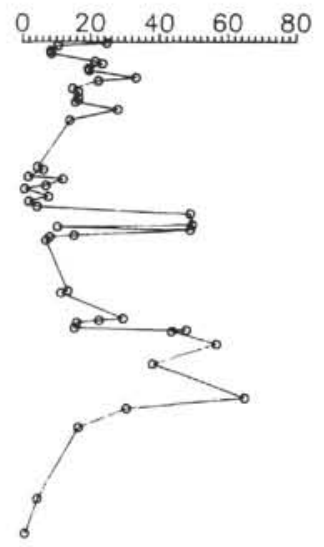

\% N. nigrinice
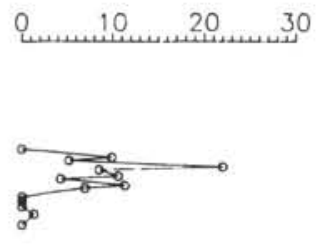

\% Pulleniatina group

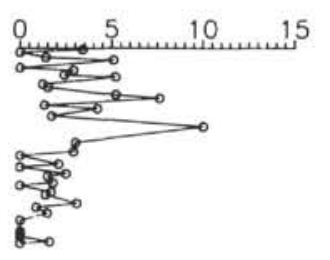

D

\$ G. tumida group

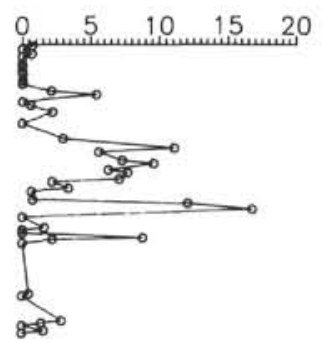

E

\% G. mayeri

$0 . \ldots . \ldots 50 . \ldots 100$

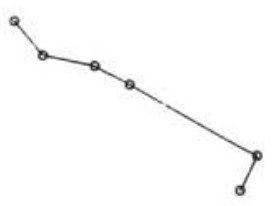

H I

\$ N. pochyderma

I

\% N. dutertrei

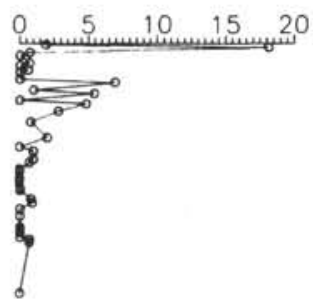

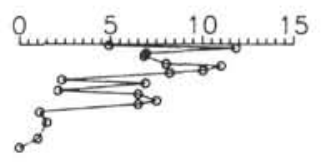

J

\% neogloboquadrinic

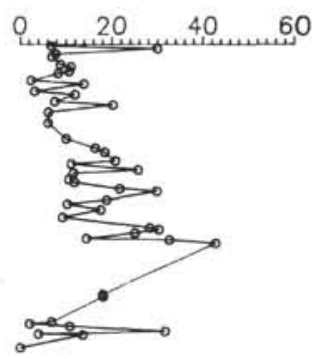

\section{K}

\$ G. trilobus

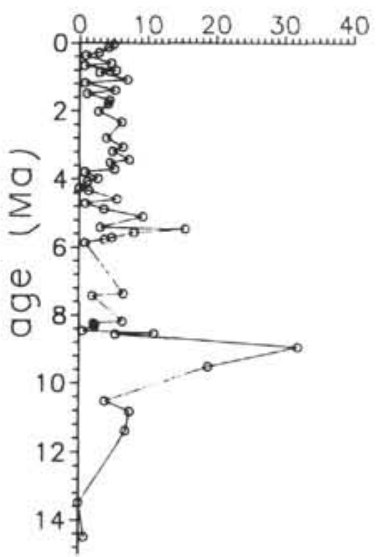

L

\% G. ruber group

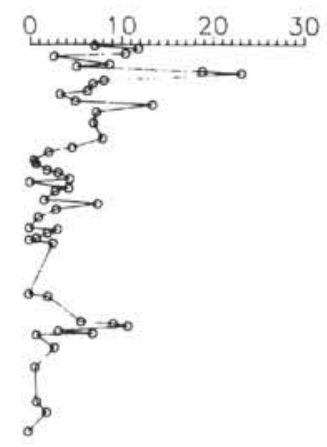

\section{M}

\$ G. obliquus

30

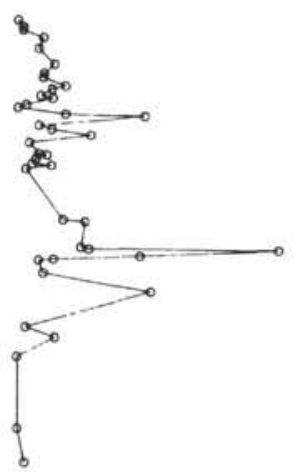

N

\$ G. altispira

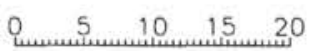

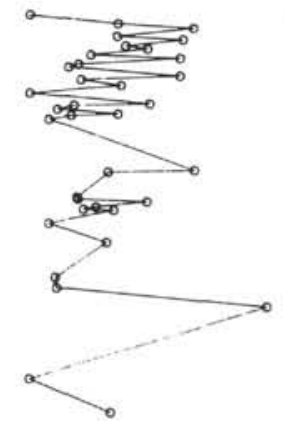

0

\% G. menardii

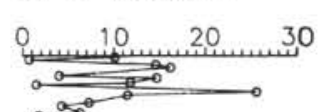

Figure 2. Plots of relative abundances of selected species in time. Note that $G$. bulloides d'Orbigny (2A), a species diagnostic for upwelling, shows a major excursion at 8.5 Ma which may be associated with the establishment of monsoonal related upwelling or an expression of a major intensification of the system. During this time the Neogloboquadrina lineage appeared with Neogloboquadrina acostaensis (Blow) (2F). At $5.5 \mathrm{Ma}$ a sharp decline in G. bulloides occurred possibly related to less upwelling during that time. After the crisis the Neogloboquadrina lineage developed further with the appearance of Neogloboquadrina nigriniae (Fleisher) (2G). 


\section{\% Globigerinoides sp.}

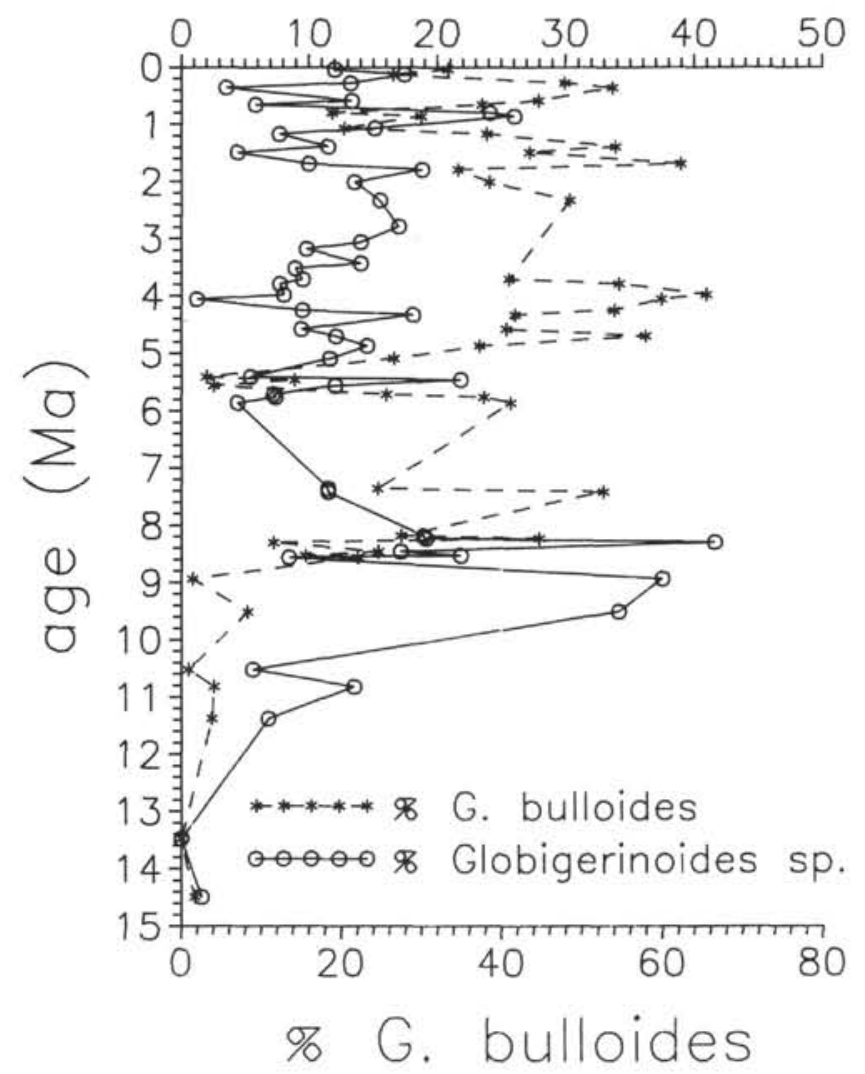

Figure 3. Plots of $G$. bulloides d'Orbigny and Globigerinoides sp. frequencies showing an inverse relationship for most part of the curve, revealing the long term variations in upwelling intensity. High $G$. bulloides and low Globigerinoides percentages indicate the upwelling periods. According to the planktonic foraminifers, upwelling started $8.5 \mathrm{Ma}$ ago with a major decrease at $5.5 \mathrm{Ma}$. This drop could represent a diminution of upwelling or alternatively other planktonic-biota like diatoms or radiolaria were dominant, possibly due to subtle changes in the chemistry of the upwelling waters. From about $5 \mathrm{Ma}$ to Recent, upwelling must have been present with minor fluctuations. 